\title{
Admiralty Jurisdiction and Limitation of Liability in Single Claim Cases
}

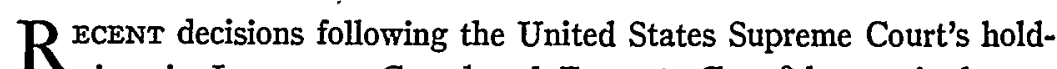
ings in Langnes v. Green ${ }^{1}$ and Ex parte Green ${ }^{2}$ have raised some interesting questions concerning the procedure the owner of a vessel may follow to obtain the benefit of the Federal Limitation of Liability Statute in cases where but a single clain is involved.

Thousands of small commercial and pleasure boats ply the coastal and inland waters of the United States. Nunerous personal injuries and deaths happen aboard such vessels every year. In many cases the value of the vessel on which an injury or death occurs is less than the amount a court or jury niay award if a negligence action is filed and judgment secured. Under certain conditions the owner of such a vessel is entitled by federal statute ${ }^{3}$ to have his liability limited to the value of the vessel, her pending freight and consumable stores. In many cases recourse to limitation of liability proceedings may save the defense thousands of dollars. Yet it is surprising how few attorneys, other than those specializing in admiralty law, have any knowledge concerning limitation of liability and the procedure whereby its benefits are obtained.

The statute was enacted by Congress in 1851 for the purpose of encouraging shipbuilding, the investment of money in ships and the enuployment of ships in commerce. ${ }^{4}$ It was undoubtedly intended priunarily for the benefit of owners of large vessels and has been of vital inportance to practically every steamship company which has had vessels involved in major collisions and other marine catastrophes. Its language is broad enough, however, to make it applicable, as well, to the owner of even a small yacht or launch..$^{5}$ It is as applicable in cases of personal injury or death on small vessels as in cases of collision

1 (1931) 282 U. S. 531.

2 (1932) 286 U. S. 437.

39 STAT. (1851) 635, 46 U.S. C. (1926) \& 783: "The liability of the owner of any vessel, for any embezzlement, loss, or destruction, by any person, of any property, goods, or merchandise, shipped or put on board of such vessel, or for any loss, damage, or injury by collision, or for any act, matter or thing, loss, damage, or forfeiture, done, occasioned, or incurred without the privity, or knowledge of such owner or owners, shall in no case exceed the aunount or value of the interest of such owner in such vessel, and her freight then pending."

4 Norwich, etc., Co. v. Wright (1872) 13 Wall. (80 U.S.) 104; Butler v. Boston \& Savannah S. S. Co. (1889) 130 U.S. 527.

5 The Linseed King (S. D. N. Y. 1928) 24 F. (2d) 967; The Alola (E. D. Va. 1915) 228 Fed. 1006; Whitcounb v. Emerson (D. Mass. 1892) 50 Fed. 128. 
between the mightiest hiners. ${ }^{6}$ The courts have declared that the statute is to be liberally construed in favor of the shipowner. ${ }^{7}$

Early cases held that admiralty had exclusive jurisdiction of limitation of liability proceedings. ${ }^{8}$ The procedure to obtain the benefit of the statute is provided by Admiralty Rules 51 to 57 of the United States Supreme Court and local United States district court rules. The usual practice is the filing of a petition in admiralty either in the district in which suit has been commenced against the shipowner or in the district in which the vessel happens to be. The petition recites the facts and circumstances on which limitation of liability is claimed and prays for the relief permitted by the statute.

After filing the petition an appraisement of the vessel's value is had, usually before a United States commissioner. When the value has been fixed and approved by the court a bond may be posted guaranteeing the payment of a judgment up to this amount, with interest and costs, or cash in such amount deposited, or the vessel itself surrendered to a trustee appointed by the court to be sold and the proceeds applied to the payment of claims. A monition is then obtained and a citation issued by the United States marshal requiring those claiming damages on account of the matter or happening which has prompted the limitation proceedings to come into court and file their claims. Notice is given by service and publication. An order restraming the further prosecution of suits pending in respect of any such claims may also be secured. Proof of the claims is made before the commissioner, and the amount of the value of the vessel and her freight pending is paid into court to be prorated amongst the claimants who have made successful proof, after trial on the merits and judgment against petitioner. If the owner desires he may contest his liability in the entirety by answering the claims and denying liability. In such event the matter is taken to trial in admiralty, and if the court finds the owner liable the entire limitation fund is prorated. If the finding is in favor of the owner, the claimants, of course, receive nothing.

In many cases of personal injury or death on board ship action is filed in a state court. Until recently it has been the usual practice of

${ }^{6}$ Craig v. Continental Ins. Co. (1891) 141 U. S. 638; Flink v. Paladini (1929) 279 U. S. 59.

7 Ibid.; California Yacht Club of L. A. v. Johnson (C. C. A.9th, 1933) 65 F. (2d) 245; The Princess Sophia (C. C. A. 9th, 1932) 61 F. (2d) 339.

8 In $r e$ Providence (S. D. N. Y. 1872) Fed. Cas. No. 11,451, at 16; Churchill v. British America (E. D. N. Y. 1878) Fed. Cas. No. 2715, at 676; In re Norwich (E.D.N.Y.1878) Fed. Cas. No. 10,361, at 439; City of Columbus (D. Mass. 1884) 22 Fed. 460; The Amsterdam (S.D. N.Y. 1885) 23 Fed. 112; Black v. Southern Pacific R. R. (N.D. Cal. 1889) 39 Fed. 565; In re Humboldt Lumber Manf'rs Ass'n (N. D. Cal. 1894) 60 Fed. 428; In re Whitelaw (N. D. Cal. 1896) 71 Fed. 733. 
admiralty counsel in such cases to file a petition to limit liability in admiralty and obtain a restraming order, probibiting further prosecution of the state court action. The entire matter thus automatically is taken into admiralty. There is no jury trial in admiralty and if the owner contests his liabihty, or in other words tries the case on its merits, a jury trial is avoided.

As early as 1886 , however, the District Court for the Southern District of New York pointed out that in a case where but a single claim was involved, and in an amount less than the value of the vessel, no purpose would be served by permitting limitation proceedings in admiralty, and it should not be presumed that in such case Congress intended to take away trial by jury..$^{9}$ In The Rosa, ${ }^{10}$ decided in 1892, suit was brought in a state court in New York for the death of a passenger on a small excursion boat. A petition to limit liability was filed in the district court and the usual restraining order requested. Special appearance and exceptions were filed to the sufficiency of the petition on the ground that there was only one claim and that the rights of the parties could be adjudicated in the state court. The exceptions were sustained. United States District Judge Brown held that section 9 of the Judiciary Act of 1789, which gave admiralty and maritime jurisdiction to the federal district courts, expressly saves "to suitors, in all cases, the right of a common law remedy, where the common law is competent to give it." This saving clause forbids interference with a suit in the state court when the whole subject matter of the rights of the parties can there be adjudicated and preserved. Where there is but a single claim, Judge Brown held, the limitation can as readily be secured in a state court as in admiralty. All that is needed is an answer pleading the statute with a statenient of the value of the vessel. The question of value then becomes one of the issues, "but the determination of such value is as appropriate and easy in the common law suit as is the determination of ordinary questions of value in the usual course of common law proceedings."

In Quinlan v. Pew11 the Circuit Court of Appeals for the First Circuit disapproved the doctrine of The Rosa on the ground that the shipowner's right to surrender the vessel to a trustee can only be accomplished by an admiralty proceeding and that the language of the original act of 1851 does not justify loolding that Congress intended any differentiation between single and plural claims. The court also pointed out that the rule of The Rosa is impracticable because owners of vessels in foreign seas could never be sure of the extent to which

9 The Garden City (S.D. N.Y. 1886) 26 Fed. 766.

10 (S.D. N.Y. 1892) 53 Fed. 132.

11 (C.C.A. 1st, 1893) 56 Fed. 111. 
they might be subject to claims and liens of various kinds. The court also pointed out that the statute was intended for the encouragement of commerce and declared it would not receive its full effect if, in a single claim case, limitation could not be obtained in admiralty.

Following the squarely conflicting decisions of The Rosa and Quinlan v. Pew the courts failed to agree as to which view to accept. In several cases the decisions approved the latter case, holding, in effect, that the state courts were without the machinery fully to adininister the himitation of liability statute even though but a single claim was presented. ${ }^{12}$ Other courts, however, followed the reasoning of The Rosa and refused injunctions in limitation proceedings in admiralty, declaring that in single clain cases the state courts were competent to give full relief. ${ }^{13}$

Prior to 1920, injured seamen had no cause of action against a shipowner for negligence, having only the right to compensation on the basis of wages to the end of the voyage, and the cost of maintenance and cure. The only exception was that if the injury was the result of unseaworthiness, they might obtain damages. In 1920 the Merchant Marine Act, popularly called the Jones Act, ${ }^{14}$ extended to seamen and personal representatives of deceased seamen the right to maintain an action for the injury or death in either the state or federal court, with the right of trial by jury. The contention was promptly made that the Jones Act impliedly repealed the limitation of liability statute in respect of claims based upon personal injury or death of seamen. The courts held, however, that the law of himitation of liability was not modified by the Jones Act and that an action by an injured seaman could be enjoined by limitation proceedings in admirality. ${ }^{15}$ Restraint of such actions in state courts was also permitted in several cases in which a single seaman's claim was presented. ${ }^{16}$

${ }^{12}$ The S. A. McCaulley (E.D. Pa. 1899) 99 Fed. 302 (approving Quinlan v. Pew); The Ocean Spray (N.D. Cal. 1902) 117 Fed. 971 (right to limitation in admiralty apparently taken for granted); The Hoffmans (S.D. N.Y. 1909) 171 Fed. 455 (stating that Quinlan v. Pew was better reasoned than The Rosa).

13 The Eureka (S.D. N.Y. 1901) 108 Fed. 672. This case was decided by Judge Brown, who wrote The Rosa opinion. He specifically refused to follow Quinlan v. Pew, declaring the limitation of liability statute contemplated pro rata distribution of the fund which could only be done in cases where there were several distinct claims and in a single claim case the state court could give full relief. In The Lotta (D.S. C. 1907) 150 Fed. 219, an injunction obtained in admiralty was ordered dissolved, but the petition to limit was retained on the basis that if the right to limit was put in issue in the state court, admiralty would assume exclusive jurisdiction of the entire case.

1441 STAT. (1920) 1007, 46 U.S.C. (1926) 688.

15 The Edward (1924) 266 U.S. 355; Charles Nelson Co. v. Curtis (C.C.A. 9th, 1924) $1 \mathrm{~F}$. (2d) 774.

16 Salmon King (W. D. Wash. 1928) 24 F. (2d) 555; Martha Buebner (D. Ore.) 1928 Am. Mar. Cas. 890; Clarence P. Howland (C.C.A. 2d, 1925) 6 F. (2d) 791. 
In White v. Island Transportation Co., ${ }^{17}$ the Supreme Court held, in an action brought by a passenger in the state court in Washington, that the owner of a vessel could file a petition to limit liability in admiralty and restrain the suit in the state court even though there was but a single claim. The court specifically stated that it did not believe a plurality of claims was essential and referred to a recent case, ${ }^{18}$ in which both the Supreme Court and counsel so assumed. The Supreme Court later pointed out, by way of dictum, in a seaman's injury case whicll arose prior to the Jones Act, ${ }^{10}$ that where there was only one possible claimant and one owner the advantage of limitation of liability might be obtaimed by proper pleading in the state court.

With the law apparently decided by White v. Island Transportation Co., the case of Langnes v. Green ${ }^{20}$ arose in the District Court for the Western District of Washington. This court held in 1929 that a fisherman who was injured during halibut operations on the fishing boat Aloha had no cause of action, having assumed the risk and been hurt by reason of his own negligence. Action had originally been brought in the state court and the owner had filed a petition to limit and to enjoin further prosecution of the state court proceedings. The district court issued a restraining order, tried the case in limitation proceedings and held there was no negligence. On appeal, the Circuit Court for the Ninth Circuit held ${ }^{21}$ that the owner was in actual charge of the vessel and had known of the conditions responsible for the injury, and that the petition for limitation of liability failed to allege that the negligence for which recovery was sought was without the owner's knowledge and privity. Therefore, the court held, the limitation proceedings should have been dismissed upon plamtiff's objections for lack of jurisdiction.

Certiorari was granted, and in Langnes $v$. Green ${ }^{22}$ the Supreme Court held that inasmuch as the petition for limitation was contested the admiralty court had jurisdiction to make a decree even though the owner had knowledge of the condition causing the injury. The Court held further, in considering what disposition should have been made of the case in the trial court, that the saving clause of the Judicial Code gives a plaintiff injured on board a vessel the right to an action in the state court and that the state court is competent to protect the owner's right to limitation of liability in a single claim case. Removal of such

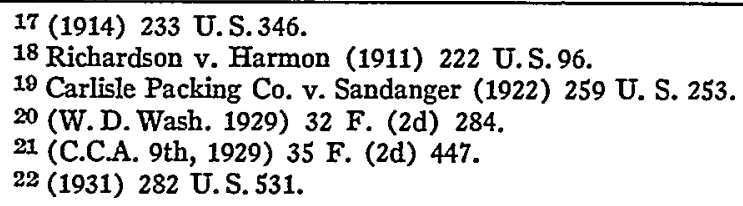


a case into admiralty destroys the suitor's common law remedy and is contrary to the saving clause of the Judicial Code. Therefore, the district court should have dissolved the restraining order and permitted the case to proceed in the state court, retaining the petition for further proceedings in case the right to limit should be contested, for only an admiralty court has jurisdiction of this issue. The decrees of both courts below were, therefore, reversed and the cause remanded for further proceedings in conformity with the decision.

White v. Island Transportation Co. is cited but not distinguished in Langnes v. Green. It might appear that the two cases are squarely in conflict since the latter definitely approves the doctrine of The Rosa, whereas the former cites and seems to approve Quinlan v. Pew. However, the only real question before the Supreme Court in the White case was whether admiralty had jurisdiction in a single claim case. Claimant urged that admiralty could not entertain the limitation proceeding because the petition disclosed only one claim. The Supreme Court's answer was simply that a plurality of clains is not essential to jurisdiction. There was no necessity for consideration of the question whether a claimant is entitled to trial in the state court even though admiralty might have jurisdiction over limitation of liability proceedings. That question was presented in the Langnes case and the Supreine Court held that admiralty could not restrain the state court action so long as the right to limit liability was conceded.

Subsequently, the shipowner in Langnes $v$. Green filed an amended answer in the state court proceedings, claiming the benefit of the limitation statute. The plaintiff, im reply, placed in issue the seaworthiness of the vessel, which raised the question of the right to bmit. The district court then held ${ }^{23}$ that the state court had no power to hear any matter with relation to the right to limit liability, or as to seaworthiness, and thereupon granted a motion of the owner for a restraining order.

The case again went to the Supreme Court on a motion for leave to file a petition for mandamus requiring the district court to show cause why it should not conform with the opinion of the Supreine Court. In Ex parte Green ${ }^{24}$ the Supreme Court lield that the state court had no jurisdiction to determine the question of the owner's right to limit liability, that if the value of the vessel was not accepted as the limit of the owner's liability the federal court was authorized to resume jurisdiction and dispose of the whole case, and that by putting in issue the right to limit the plaintiff subjected liunself to further procedure

23 (W. D. Wash. 1932) 56 F. (2d) 647.

24 (1932) 286 U.S. 437. 
in the district court in admiralty. The Court, however, granted plaintiff a reasonable time to elect whether to withdraw the admiralty issue.

Langnes v. Green has apparently settled the old controversy raised by the doctrines espoused by The Rosa and Quinlan v. Pew, respectively, in favor of Judge Brown's reasoning in the former case. Subsequent cases indicate this may now be taken for granted. It has even been held that a claimant's right to a state court hearing and jury trial, in a single claim case, may not be avoided by the shipowner by filing a petition to limit before claimant has filed suit. ${ }^{25}$ It has been held, lowever, that a United States district judge may not of his own accord nrodify a restraining order so as to permit continuance of an action in a state court. In effect, this requires that the state court plaintiff must make application for such an order ${ }^{26}$ It has also been held that a shipowner may file a petition to limit liability in admiralty after judgment has been obtained against him in a state court action, and obtain a stay of execution until trial of the issue of lis right to limited liability. ${ }^{27}$ It is not requisite that the riglit to limit be pleaded as a defense in the state court action.28

In Kearny, ${ }^{29}$ the District Court for the Eastern District of New York had before it a motion to dissolve a restraining order issued in limitation proceedings in a case in which an injured deck hand had filed a state court action. Shortly before the trial was reached the owner of the vessel filed a petition to limit. No other claims were presented. Plaintiff did not contest the right to limit, and in fact expressly agreed to the right to limit, but did make issue as to the value of the vessel, refusing to concede the value alleged by the owner. The court held that plaintiff had no right to lave submitted to a common law jury the question of the value of the owner's interest in the vessel, which was the real controversy between the parties. The reasons given were that the jury is apt to be influenced in fixing the value of the vessel by its feelings regarding the damages to wlicli plaintiff may be entitled, and

25 In re Putnam (C.C.A. 2d, 1932) 55 F. (2d) 73, holding that the ship owner could not deprive claimant of a choice of forum by filing a petition to limit before a single claim suit had been filed, and ordering a restraining order directed to such a claimant vacated. The case also held that the fact that claimant filed a claim in the limitation proceedings did not bar recourse to the state court. The Supreme Court denied certiorari in this case. (1932) 286 U.S. 558.

26 The Nanuet (C.C.A. 2d, 1932) 55 F. (2d) 222. Cas. 910.

$2 \pi$ Petition of Moran Bros. Contracting Co. (E.D.N.Y.) 1932. Am. Mar.

28 The Norco (C.C.A. 9th, 1933) 66 F. (2d) 651, rev'g (W.D. Wash. 1932) $1 \mathrm{~F}$. Supp. 932, which held that a shipowner who failed to plead limitation in the state court waived this right and could not thereafter petition to limit. The decision of the Circuit Court of Appeals was affirmed by the Supreme Court in Larsen v. Northland Transp. Co. (1934) 78 L. Ed. 737.

29 (E. D.N. Y. 1933) 3 F. Supp. 718. 
that the admiralty law has long indicated a particular procedure for ascertainment of value which is an integral part of the right to limitation of liability. This case has been settled and will not be appealed.

The law, therefore, now appears settled that in any case in which there is a single claim for personal injury or death on board a vessel the claimant has the right to maintain an action in the state court, and such suit cannot be restrained by limitation proceedings in admiralty, subject to the qualification that claimant must admit the right to limit and, by the doctrine of the Kearny case, the amount of the limited liability of defendant if judgment be rendered for plaintiff. If either or both of these matters are contested, limitation proceedings may be filed in admiralty, which has exclusive jurisdiction, and the state court action will be restrained.

If the right to limit to a fixed amount is conceded, the state court action may proceed to judgment. This, however, raises the procedural question of how the right to limit will be conceded. Assuming limitation of liability has been pleaded as a separate defense in the answer (which would be the normal method of setting it up in the state court action), how can the claimant be compelled to make his election to concede or deny the right to limit? If he concedes, the case proceeds in the state court. If he denies, limitation proceedings may be instituted and the case taken into admiralty. In jurisdictions where reply to the answer is required the claimant must, of course, plead to the limitation of liability allegations, and thereby either concede or deny the right to limit. In California and many other jurisdictions, however, no pleading to the answer is required or permitted by the codes. What is the situation in these states?

It would seem unsound to permit the shipowner to take the position that because the separate defenses set forth in the answer are deemed denied, claimant has not conceded the right to limit, and that a petition to limit can, therefore, be filed in admiralty. On the other hand, it does not seem fair to compel the shipowner to wait until the trial before he can require claimant to make an election. And if he must wait until trial, must the election be made before the trial begins or after the evidence is in? In either event, if claimant eventually elects to deny the right to limit, can a petition then be filed in admiralty and the state court trial be restrained, or will it be permitted to continue and the admiralty court accept the judgment rendered in so far as the issue of negligence is concerned, reserving only the issues of the right to limit and the value of the vessel? These questions have not yet been presented to the courts. It is submitted that the claimant should not be permitted to delay making his election until the time of trial 
in the state court arrives, but should be required, in some manner, either to concede or deny the right to limit sometime in advance of the trial date.

Assuming concession of the shipowner's right to limit and trial of the case in the state court, the shipowner may be liable up to the value of his vessel, her pending freight and consumable stores. The question then arises as to the power of the state court to fix the value. The Kearny case holds the state court has no power to fix the value and if the value specified by the owner is not accepted this issue must be decided in admiralty. This opinion may or may not be followed in the higher courts.

Under the $\operatorname{Norco}^{30}$ decision the shipowner has the right, if he so desires, to entirely disregard the issue of limitation of liability im the state court and institute limitation proceedings in admiralty after judgment. In cases where the claimant is sure to concede the right to limit and that right can unquestionably be proved, it would seem better to follow this procedure than plead limitation in the state court. If the Kearny decision should not be followed, this will avoid presentation of the issue of value to a jury which, in most cases, is apt to fix a higher valuation than the cominissioner in admiralty. However, if there is some question as to the shipowner's right to limit, it may be preferable to plead limitation in the state court, which will require clainant to elect whether he will admit the right to limit. If he does, the case may proceed in that court and the shipowner is not required to prove that he is entitled to limit. If claimant does not concede the right to limit, the case may be taken into admiralty in its entirety.

Another alternative is the immediate filing of a petition to limit in admiralty and the obtaining of a restraining order. This will require claimant to move to vacate the order and force immediate concession of the right to limit. Under the rule of the Kearny case it may also be urged that claimant is required to concede the amount of the value of the vessel before the restraining order will be vacated.

The entire situation is complicated, and it will require further decisions to settle definitely where the shipowner stands and what his rights may be in cases of this character.

John C. McHose.

Los ANgeles, Carifornia.

${ }^{30}$ Supra note 28. 